\title{
Detection of intracellular Helicobacter pylori in Candida. SPP from neonate oral swabs
}

\author{
DLillian Matamala-Valdés' \\ Kimberly Sánchez-Alonzo ${ }^{1}$ \\ Cristian Parra ${ }^{1}$ \\ Katia Sáez ${ }^{1}$ \\ Alejandro Aguayo-Reyes ${ }^{1}$ \\ Apolinaria García ${ }^{1}$
}

1. Universidad de Concepción, Víctor Lamas 1290, casilla 160 C, Concepción, Región del Biobío, Chile.

http://dx.doi.org/10.1590/1806-9282.64.10.928

\section{SUMMARY}

BACKGROUND: There is evidence of detection of Helicobacter pylori (H. pylori) in the stool of newborns and in the yeast that colonizes the oral cavity of this age group. However, there is a lack of research to confirm it. This study proposes to determine the existence of the bacteria at an early age, specifically in newborns.

OBJECTIVE: To identify intracellular H. pylori in oral yeasts and to detect antigens of the bacteria in newborn stools.

METHODOlogy: Cross-sectional and descriptive study. Samples were obtained from infants (oral swab and meconium). Identification of yeast species was performed using the following techniques: CHROMagar Candida, Germinal Tube Test and API Candida Identification System, then the yeasts were observed by light microscopy and fluorescence. Detection of $H$. pylori antigen in meconium and PCR were performed to amplify specific genes of the bacterium ( $r R N A 16 S$, cagA, vacA s1a, vacA s1b, vacA s2, vacA m1, vacA m2 and dupA). RESULTS: Intracellular H. pylori was detected in yeast of the species Candida glabrata (C. glabrata) isolated from an oral swab of a newborn.

CONCLUSION: The results of this study evidenced the existence of intracellular H. pylori in newborns.

KEYWORDS: Helicobacter pylori. Infant, Newborn. Candida glabrata. Candida albicans. Mouth.

\section{INTRODUCTION}

Infections caused by H. pylori are one of the most common types in children and adults'. Most of the diseases caused by $H$. pylori in adults are the result of an infection acquired during childhood², with intra-familial being one of the main routes of transmission of the bacteria ${ }^{3}$.

Studies have shown that the presence of H. pylo$r i$ in individuals are related to their socio-economic level and the level of development of their country of residence, since countries with low development levels have a prevalence of up to $84 \%^{5}$ of $\mathrm{H}$. pylori infection amongst children, while in highly developed countries, such as Australia, that number is lower than $15 \%{ }^{6}$. Chile is ranked amongst highly developed countries, according to the United Nations classification $^{7}$, along with Brazil and Turkey, which present a reported prevalence of $47.5 \%^{8}$ and $23.9 \%^{9}$, respectively. According to Jamile et al. ${ }^{4}$, in 2013 , there was a reported prevalence of $18.1 \%$ of $H$. pylori infections among school children aged between 8-15 in a school in Santiago, Chile. Currently, there are no studies in Chile that explore the epidemiology of $\mathrm{H}$. pylori in the neonate population, but there are studies in the pediatric population ${ }^{10}$. 
H. pylori can cause several gastrointestinal diseases, such as chronic and acute gastritis, duodenal and gastric ulcers, and MALT lymphoma (lymphoma involving the mucosa-associated lymphoid tissue) ${ }^{1,11}$. In addition, it is the main risk factor for the development of gastric cancer ${ }^{12}$. On the other hand, H. pylori is associated with problems beyond the intestines, such as growth below normal, malnutrition and anemia, especially in children. ${ }^{10}$ For these reasons, the diagnosis and treatment of this bacteria in children is of the utmost importance.

The diagnosis of $\mathrm{H}$. pylori infection has proved to be more challenging in children than in adults ${ }^{13}$. Non-invasive diagnostic methods have been used for this age group, despite its relatively low diagnostic accuracy, since invasive procedures, such as endoscopy, are difficult to apply in newborns and/or small children. Amongst non-invasive methods, the measurement of antigens in the stool is easy to apply and has shown excellent results ${ }^{13}$.

There are several studies that demonstrate that bacteria can survive in vacuoles of eukaryotes, such as free-living amebas, as is the case with Enterobacter aerogenes, Aeromonas hydrophila, Legionella pneumophila, which were found to be able to survive in vacuoles of Acanthamoeba castellanii, through the inhibition of phage-lysosome fusion ${ }^{14}$. They observed the same phenomenon with Pseudomonas aeruginosa, which grew inside the cells in amebas of different genres isolated from hospital tubes ${ }^{15}$. With this background, Siavoshi et al. ${ }^{16}$, determined a relationship between $H$. pylori and the oral cavity yeast, since the later organism is found as a commensal on the surface of the mucosa of the human oral cavity, intestines, and vagina. In the same way, that research group isolated yeast from the oral cavity of dyspeptic patients and were able to amplify specific PCR genes of H. pylori (ARNr 16S, cagA, vacA e ure $A B$ ) and observed through cellular optical microscopy intracellular H. pylori inside the vacuoles of the Candida yeast. They concluded that H. pylori possibly used the eukaryote as protection from distress conditions. In addition, the infection of neonates by Candida albicans species occurs very early, through vertical transmission when they go through the birth canal, causing an oral infection with yeast ${ }^{17 .}$ That fact led to the objective of this investigation, which is to identify intracellular $H . p y$ lori in yeats from oral swabs and H. pylori antigens from newborn stools.

\section{PATIENTS AND METHODS}

\section{Type of study:}

This is a quantitative study, observational and descriptive, of cross-sectional time, approved by the Ethics Committee under the code 06/15-22.

\section{Study population}

Term newborns (37 weeks or more), born at the Guillermo Grant Benavente Hospital, between $\mathrm{Au}$ gust and December 2015, in the City of Concepcion, Biobío, Chile.

\section{Inclusion criteria}

Term newborns, born at the Guillermo Grant Benavente Hospital, from women who accepted to participate in the study by signing the informed consent form in order for us to obtain samples from their newborns. The Informed Consent Form could also be signed by the newborn's tutor.

\section{Exclusion criteria}

Premature newborns, newborns whose mothers or tutors refused to sign the informed consent form at the moment the samples were collected, and term newborns who were hospitalized at the moment the samples were collected.

\section{Oral swab collection}

The samples oral collected through oral swabs in all 53 newborns, at the day of release from the maternity ward, by scraping the cheeks, gums, and under the tongue. The samples were then placed in Stuart tubes previously identified and stored in a hermetically container at room temperature. Later, the samples were transferred to the Bacterial Pathogenicity Laboratory of the Biosciences Faculty of the University of Concepcion, where they were analyzed ${ }^{18}$.

\section{Stool sample collection}

The meconium from the participant newborns was collected in previously identified wide mouth containers. The samples at the day of release from maternity ward and were stored in a hermetically sealed container with ice. They were then transferred to the Bacterial Pathogenicity Laboratory to be analyzed ${ }^{16}$.

\section{Processing of samples to isolate yeast}

Each sample from the oral swabs of newborns was sown in Petri plates 94X16 containing $20 \mathrm{ml}$ of 
Sabouraud Dextrose Agar prepared according to the manufacturer's instructions and supplemented with chloramphenicol, incubated at $37^{\circ} \mathrm{C}$ for $24-48$ hours.

Then, with a curve handle, an inoculum was removed from the colonies and spread in lines in 94x16 Petri plates containing CHROMagar Candida medium prepared in accordance with the manufacturer's recommendations, incubated at $37^{\circ} \mathrm{C}$ for 72 hours, and checked at every 24 hours to see if there were growth and differentiation of yeasts by color. Tests of germ tube were conducted in green colonies to differentiate between C. albicans and C. dubliniensis of non-albicans Candida.

Confirmation of the Candida species was performed using the API ${ }^{\circledR}$ system for the identification of the Candida yeast, following the manufacturer's recommendations (BIOMÉRIEUX, France).

\section{Detection of intracellular H. pylori in yeast:}

For the intracellular detection of $H$. pylori in the yeast identified in oral samples from newborns, a drop of saline solution at $0.9 \%$ was deposited in a 22.4X76.2 mm container, then using a curve handle, an inoculum of a colony was deposited at random, and a 22x22 $\mathrm{mm}$ cover was placed over the sample for observation in the microscope with 40X objective, figure1. Then, H. pylori were detected with immunofluorescence using rabbit polyclonal IgG anti- $H$. pylori antibodies marked with FITC, whose concentration was $5,000 \mathrm{mg} / \mathrm{ml}$, with a wavelength of 528 nm. The ATCC 90028 strain of C. albicans was used as a negative control and the ATCC 43504 strain of $H$. pylori infection as positive control ${ }^{16}$.

The images were obtained with DIC (differential interference contrast) and fluorescence with laser stimulation Ar488 nm and emission between 490$560 \mathrm{~nm}$. The fluorescent images correspond to a with a $2-4 \mu \mathrm{m}$ thick plan. The acquisition software used was Zen 2012.

To perform the intracellular H. pylori genotyping of yeasts from oral swabs from newborns, their DNA was extracted using the UltraClean ${ }^{\circledR}$ Microbial DNA Isolation kit. The DNA was quantified, and the ARNr16S, cagA, dupA, vacAs1a, vacAs1b, vacAs2, va$c A m 1$, vacAm2 genes were amplified using the SapphireAmp ${ }^{\circledR}$ Fast PCR Master Mix Kit (TAKARA BIO INC, Japan).

Once the genes were amplified, we conducted electrophoresis in agarose gels (Lonza, USA) at $2 \%{ }^{19}$.

Detection of H. pylori antigens in meconium:

We used the Premier Platinum $\mathrm{HpSA}^{\circledR}$ Plus Kit (Meridian Bioscience Europe, Italy) following the manufacturer's recommendations. The reaction was read in a spectrophotometer (TECAN, Switzerland); the controls used in this trial were those supplied with the kit.

\section{Data Analysis:}

Of 108 newborns, 43 mothers abandoned the study, 2 mothers went home before the official release, and 4 newborns remained hospitalized. There-

FIGURE 1: DIRECT EXAMINATION OF YEAST SAMPLES FROM NEONATE ORAL SWABS, WITH 1OOX MAGNIFICATION. IMAGE (A) CORRESPONDS TO THE ATCC 90028 STRAIN, USED AS THE CONTROL, AND IMAGE (B) CORRESPONDS TO THE YEASTS FROM THE CLINICAL SAMPLE. THE DOTTED LINES INDICATE THE NUCLEUS OF THE YEAST, AND THE DATES INDICATE INTRACELLULAR INCLUSIONS.

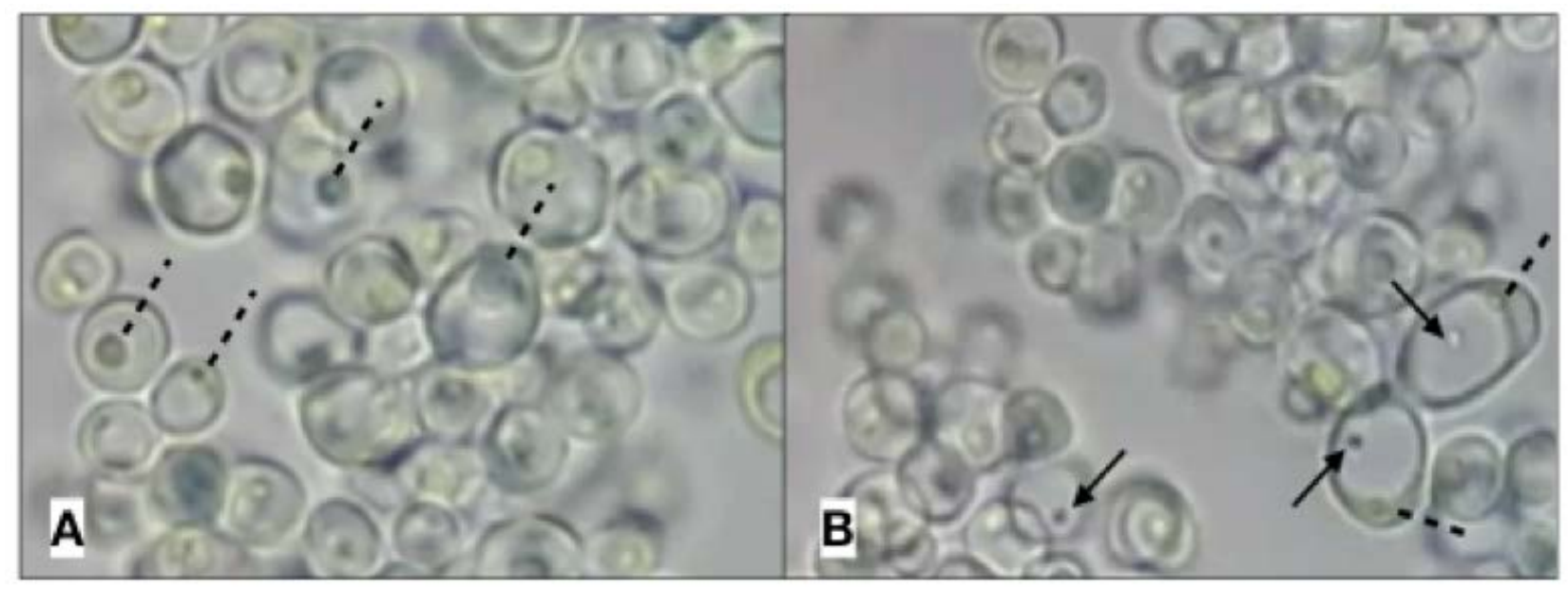


fore, the total number of newborns enrolled in the study was 53 , of which 28 were males and 25 females.

The data obtained from the samples were entered into an Excel database and were analyzed using SPSS version 19.0. For this study, only descriptive analyzes were performed, and the qualitative variables were presented as absolute frequency and relative percentage.

TABLE 1: IDENTIFICATION OF YEAST SPECIES FROM NEONATAL ORAL SWABS.

\begin{tabular}{l|l|l} 
Neonatal oral swabs & \multicolumn{1}{l}{ Frequency } & Percentage (\%) \\
\hline C. albicans & 2 & 3.8 \\
\hline C. glabrata & 2 & 3.8 \\
\hline Negative & 49 & 92.4 \\
\hline Total & 53 & 100 \\
\hline
\end{tabular}

TABLE 2: DETECTION OF H. PYLORI IN NEONATAL ORAL YEAST-INFECTIONS THROUGH CRP.

\begin{tabular}{|c|c|c|}
\hline ARNr16S for H. pylori & Frequency & Percentage (\%) \\
\hline Negative & 52 & 98.1 \\
\hline Positive & 1 & 1.9 \\
\hline Total & 53 & 100 \\
\hline
\end{tabular}

TABLE 3: RELATIONSHIP BETWEEN YEAST SPECIES FOUND IN NEONATAL ORAL SWABS AND TYPE OF DELIVERY.

\begin{tabular}{l|l|l|l|l}
\multicolumn{3}{c}{ C-section } & Vaginal \\
\hline Oral swab & N & $\%$ & N & $\%$ \\
\hline C. albicans & 0 & 0 & 2 & 100 \\
\hline C. glabrata & 1 & 50 & 1 & 50 \\
\hline Negative & 12 & 24.5 & 37 & 75.5 \\
\hline Total & 13 & 24.5 & 40 & 75.5 \\
\hline
\end{tabular}

TABLE 4: IDENTIFICATION OF NEONATES INFECTED WITH INTRACELLULAR H. PYLORI THROUGH ANTIGENS IN STOOL AND CRP.

\begin{tabular}{|c|c|c|c|}
\hline Variable & & Frequency & Percentage (\%) \\
\hline \multicolumn{4}{|c|}{ H. pylori antigen } \\
\hline & Negative & 53 & 100 \\
\hline \multicolumn{4}{|c|}{ ARNr16S for H. pylori } \\
\hline & Negative & 52 & 98.1 \\
\hline & Positive & 1 & 1.9 \\
\hline \multicolumn{2}{|l|}{ Total } & 53 & 100 \\
\hline
\end{tabular}

\section{RESULTS}

The total number of oral swabs samples from newborn babies was 53, of which the majority, 92.4\% $(\mathrm{n}=49)$, had negative results for yeast. Out of the positive samples, we found the same percentage for C. albicans, 3.8\% $(\mathrm{n}=2)$ and C. glabrata, $3.8 \%(\mathrm{n}=$ 2) $\%$ (Table 1).

We managed to detect intracellular inclusion by direct examination using optical microscopy of the yeast samples, obtained from the oral mucosa of newborns, in only one of these samples (corresponding to $1.9 \%, \mathrm{n}=1$ ), as shown in Figure 1. It is noteworthy that the strain of yeast detected then corresponded to the species C. glabrata. After applying immunofluorescence, we confirmed that this inclusion corresponded to the H. pylori species, also through amplification of 16S rRNA gene of $H$. pylori (Table 2).

Once we confirmed the intracellular inclusion corresponded to the H. pylori species, we proceeded to carry out the genotyping of the strain detected. The genotype of intracellular $\mathrm{H}$ pylori strains in the C. glabrata species, based on the genesis of virulence dupA cagA and vacA was cagA-, dupA-, vacAs1a.

Depending on the type of delivery, we can say that there was only one positive culture for oral yeasts in newborns from cesareans, corresponding to the $C$. glabrata species, and three positive cultures in neonates born from vaginal delivery, two cultures corresponding to the $C$. albicans species and one to $C$. glabrata. For all cultures positive for yeasts, we were able to detect and identify only in one of them the intracellular presence of $\mathrm{H}$. pylori; that was in the yeast of the $C$. glabrata species from a newborn by vaginal delivery (Table 3).

With respect to the detection of $H$. pylori antigens in meconium (first evacuation of the newborn), we found no positive samples (Table 4).

\section{DISCUSSION}

In Chile, $73 \%$ of the adult population have antibodies against $H$. pylori. The infection is acquired in childhood, presenting the highest rates of infection before the age of 10 years ${ }^{17,20}$.

In this study, we determined the endosymbiotic relationship between $\mathrm{H}$. pylori and yeasts of the Candida strains isolated in samples from oral swabs. In addition, we analyzed the existence of $H$. pylori antigens in meconium obtained from term newborns to correlate the presence of intracellular H. pylori in 
yeasts and the possibility of detection of such antigens in stool samples, a similar study to that by Siavoshi et $a l^{21}$.

There is evidence that the age at which the infection is acquired could be an important determinant of its course. When the infection occurs in small children, it presents itself as pangastritis, which is associated with the possibility of developing ulcers and carcinoma. When the infection occurs in older children, it is associated with antral-predominance gastritis, with the possibility of developing duodenal ulcers $^{21}$. In turn, the complications caused by the infection are due to a combination of factors, which include bacterial virulence, the characteristics of the host and the environment ${ }^{22.23}$.

According to a recent report, up to $28 \%$ of pregnant women can have vaginal Candida $s p p^{24}$. This is due to an increase in the estrogen level, which increases glycogen in the vagina, increasing the adhesiveness of vaginal epithelial cells and strengthening the formation of mycelium with the presence of specific receptors of estrogen. In addition, reduced local immunity can also facilitate vaginal colonization and a subsequent infection ${ }^{25}$.
Between $75-90 \%$ of vulvovaginitis in pregnant women is caused by C. albicans, while the other yeasts are called non-albicans species, among which is the Candida glabrata ${ }^{26}$, also found in the oral swabs from newborns in this study and which can be congenitally acquired, i.e., through the presence of micro-organisms on a colonized vagina transported to the uterine cavity ${ }^{27}$. This occurs, in the majority of cases, through intact membranes or the subclinical rupture of membranes prior to the delivery. Once the membranes are penetrated, the micro-organism spreads from the amniotic fluid to the fetal skin and, subsequently, to the respiratory and digestive tract ${ }^{27}$.

The newborn can swallow or aspire to the infected amniotic fluid at the time of delivery, whether it as a vaginal delivery or cesarean section ${ }^{27}$.

In this study, 12 newborns were delivered by cesarean section; of these, one had a positive result for C. glabrata; and of 40 newborns through vaginal delivery, 1 had a positive result for C. glabrata and 2 for C. albicans. This suggests that there may be a greater transmission of yeasts from mother to newborn during the passage through the birth canal, which would not happen during cesarean sections. This

FIGURE 2: IMMUNOFLUORESCENCE STUDY WITH H. PYLORI ANTIBODIES LABELED WITH FITC. IMAGE A: BRIGHTFIELD MICROSCOPY OF THE NEGATIVE CONTROL C. ALBICANS ATCC 90028 STRAIN. IMAGE B: IMMUNOFLUORESCENCE MICROSCOPY WITH C. ALBICANS ATCC 90028 STRAIN, WITH NO SIGNS OF FLUORESCENCE. IMAGE C: DARK-FIELD MICROSCOPY OF H. PYLORI ATCC 43504 STRAIN (POSITIVE CONTROL). IMAGE D: IMMUNOFLUORESCENCE MICROSCOPY THAT SHOWS THE PRESENCE OF INTRACELLULAR H. PYLORI IN YEAST SAMPLES FROM NEONATAL ORAL SWABS. PLAN APOCHROMAT OBJECTIVE 63 X NA 1.4 PLUS ZOOM UP TO 2X
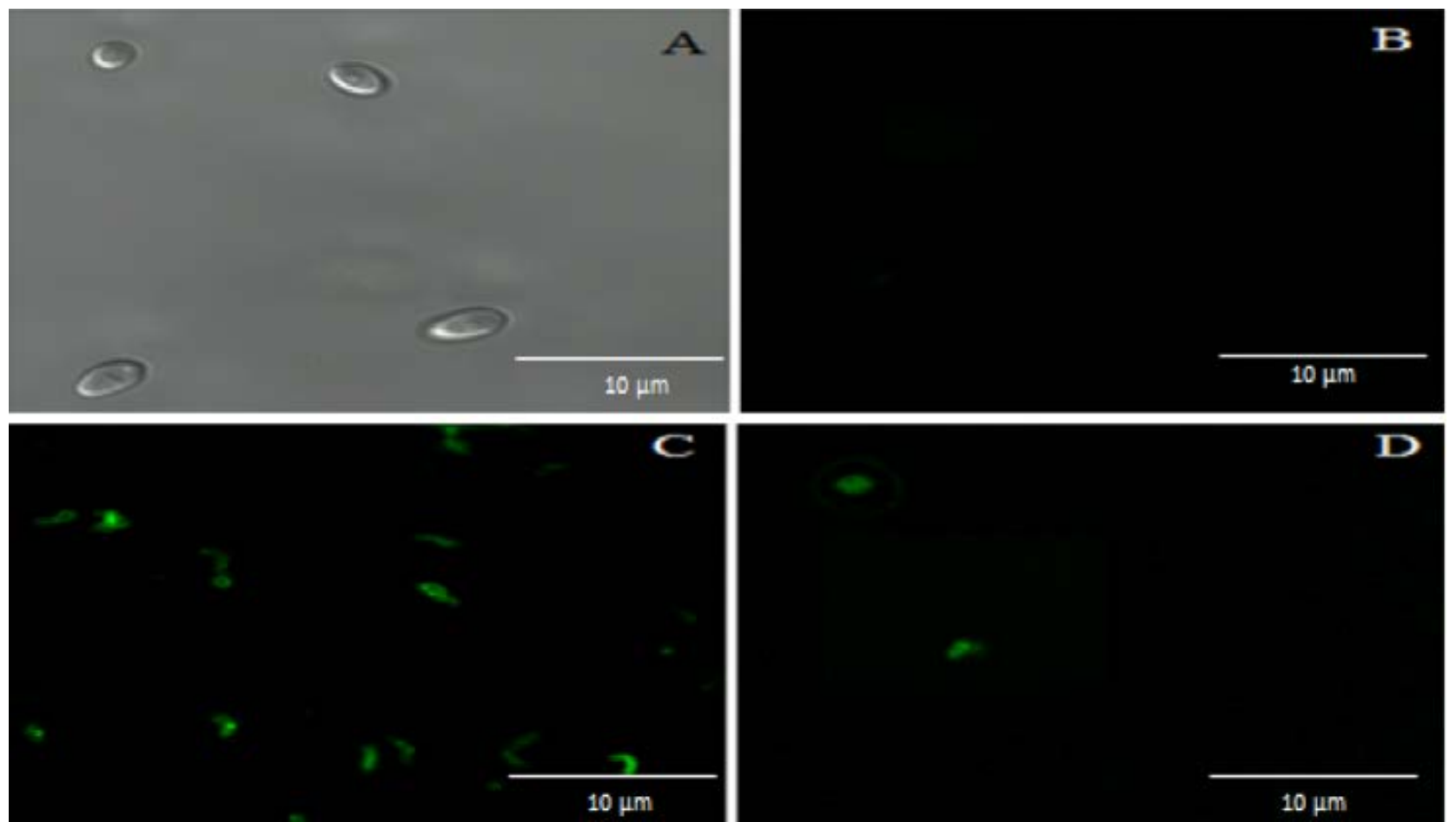
may be due to a greater contact of the newborns with the mothers' vaginal fluids while passing through the birth canal or the contact with the amniotic liquid while rupturing membranes in labor, compared with cesarean sections without going into labor and with no premature rupture of membranes, in which case there is no contact with vaginal secretions.

However, in this case, a positive culture is justified by the rupture of membranes before the cesarean section.

There is evidence from the 1980's that show C. albicans as the main agent of fungal infections in newborns, in 80 to $90 \%$ of cases ${ }^{27.28}$. However, the recent literature already shows there is a tendency of the emergence of other species, such as C. parapsilosis and C. glabrata ${ }^{27}$, as we have seen in this study.

Some researchers consider the vertical transmission as a way of newborns acquiring an $\mathrm{H}$. pylori infection from their mothers during their passage through the birth canal ${ }^{16}$. So far, there have been no reports that bacteria have been isolated directly from the vaginal mucosa. However, a symbiotic relationship has been proposed between the Candida species and H. pylori bacteria ${ }^{28.29}$. Siavoshi et al. ${ }^{21}$, in 2005 , isolated yeast from the oral cavity and were able to determine through PCR the presence of $H$. pylori genes (ARNr 16S, cagA, vacA, and ureAB) and observed through cellular optical microscopy the intracellular H. pylori inside the vacuoles of the Candi$d a$ yeast. They concluded that $H$. pylori possibly used the Candida as protection from distress conditions. Those findings are in agreement with our study since we detected intracellular $H$. pylori in C. glabrata isolated from oral swabs from a newborn using PCR to amplify specific genes of the bacteria.

The research of the gene of virulence in clinical isolates of $H$ pylori, as the latter described, constitutes an important tool for characterizing and detecting specific strains that present a greater potential of pathogenicity. The genotyping of $\mathrm{H}$. pylori strains found intracellularly in C. galabrata and based on virulence genes dupA, cagA, and vacA had the following results: cagA-, dupA-, vacAs1a. It is important to highlight that the vacuolating cytotoxin VacA is secreted around $50 \%$ of $H$. pylori strains and causes vacuolar degeneration of gastric epithelial cells and ulceration of the gastric mucosa. ${ }^{30,31}$.

Genotyping studies of strains of $H$. pylori from Chilean patients showed that the presence of the
cagA gene or the allelic variant vacAs1 has no predictive value for estimating risks of severe gastric pathologies. However, when the strain has the cagAt/ vacA $s 1 \mathrm{~m} 1$ genotype, there is a higher risk of developing peptic ulcer ${ }^{19.32}$.

The diagnosis of $H$. pylori infection has proved to be more challenging in children than in adults ${ }^{32}$. Reviews have described the existence of few studies that evaluate the effectiveness of different non-invasive methods to establish the diagnosis of infection in children ${ }^{17.33}$.

In this way, one of the objectives of this study was to detect $H$. pylori antigens in the meconium (HpSA) of term newborns. This method, compared with the search for $\mathrm{H}$. pylori antigens through serology, is not invasive, corresponding to the painless collection of a sample, which is easy to obtain and presents good results (94\% sensitivity and $97 \%$ specificity).

In this study, none of the 53 newborns had positive results for $\mathrm{H}$. pylori antigens in their meconium, which correlates with what was described in the Chilean study by O'Ryan et al.10, in which only one of 102 stool samples collected at 3 months of life had positive results. In that study, they evaluated the persistent or transitory infection by $\mathrm{H}$. pylori in a population of children with follow-up until 5 years of life, in addition to evaluating the dynamics of infection in the group.

The fact that we did not find infected newborns in our group may be due to the time in which the sample was taken, three days after birth, and the small amount of meconium collected. Therefore we suggest an increased sample size and number of samples in future studies.

\section{CONCLUSIONS}

The H. pylori infection was detected intracellularly in C. glabrata by immunofluorescence, which was performed using rabbit polyclonal antibodies IgG anti- H. pylori marked with FITC, and was confirmed by the presence of $H$. pylori-specific genes in oral swabs from newborns.

The genotype of intracellular H. pylori in the $C$. glabrata species in oral swabs from newborns, based on virulence genes cagA, dupA e vacA, was cagA-, dupA-, vacAs1a, determined through PCR.

It will be necessary to monitor these newborns to detect when in their lives they are infected with $H$. 
pylori and use other microbiological techniques, such as real-time PCR, for the detection of yeasts in oral swab samples, as well as increase the amount of meconium in the samples and, additionally, perform a search for antigens in stool samples posterior to the meconium of newborns.

This study demonstrates the presence of $\mathrm{H}$. pylori in oral swab samples from newborns in an endosymbiotic relationship with C. glabrata.

\section{ACKNOWLEDGMENTS}

Scientific Initiation project at the University of Concepción, code 215.084.016-1.OIN.

Ethical aspects: The authors of this research declare that they have no conflict of interest. This research was approved by the Health Service Ethics Committee of Concepción-Chile, with the code 1522-06 and was approved on July 5, 2015.

\section{RESUMO}

ANTECEDENTES: Há evidências de detecção de Helicobacter pylori (H. pylori) em fezes de recém-nascidos, como também dentro de leveduras que colonizam a cavidade oral dessa faixa etária. No entanto, faltam investigações que confirmem esses achados.

OBJETIVO: Identificar H. pylori intracelular em leveduras de origem oral e detectar antígenos dessa bactéria em fezes neonatais.

METODOlogiA: Estudo transversal e descritivo. As amostras foram obtidas de bebês (zaragatoa oral e mecônio). As identificações das espécies de leveduras foram realizadas utilizando as seguintes técnicas: CHROMagar Candida, teste de tubo germinativo e sistema de identificação API Cândida. As leveduras foram observadas por microscopia óptica e fluorescência. Realizou-se a detecção de antígeno de H. pylori em mecônio e PCR para a amplificação de genes específicos desta bactéria ( $R$ RNA16S, cagA, vacA s7a, vacA s1b, vacA s2, vacA $m 1$, vacA $m 2$ e dupA).

RESULTADOS: Foi detectado H. pylori intracelular em leveduras da espécie Candida glabrata (C. glabrata) isoladas a partir de zaragatoas oral de um recém-nascido.

CONCLUSÃO: Os resultados deste estudo evidenciaram a existência interna de levedura de H. pylori em recém-nascidos.

PALAVRAS-CHAVE: Helicobacter pylori. Recém-nascidos. Candida glabrata. Candida albicans. Boca.

\section{REFERENCES}

1. Yang HR. Updates on the diagnosis of Helicobacter pylori infection in children: what are the differences between adults and children? Pediatr Gastroenterol Hepatol Nutr. 2016;19(2):96-103.

2. Rothenbacher D, Inceoglu J, Bode G, Brenner H. Acquisition of Helicobacter pylori infection in a high-risk population occurs within the first 2 years of life. J Pediatr. 2000;136(6):744-8.

3. Zacur M, Duarte D, Petit S, Ibieta F, Nunez M. Helicobacter pylori en niños. Pediatr. 2006;33(1):26-31.

4. Jaime F, Villagrán A, Serrano C, Cerda J, Harris PR. Frequency of Helicobacter pylori infection in 144 school age Chilean children. Rev Med Chile. 2013;141(10):1249-54.

5. Costa A, Figueiredo C, Touati E. Pathogenesis of Helicobacter pylori infection. Helicobacter. 2009;14(Suppl 1):15-20.

6. Hunt RH, Xiao SD, Megraud F, Leon-Barua R, Bazzoli F, van der Merwe S, et al. Helicobacter pylori in developing countries. World Gastroenterology Organisation Global Guideline. J Gastrointestin Liver Dis. 2011;20(3):299304.

7. Organización de Naciones Unidas. Human development report 2009 [cited 2018 Jan 8]. Available from: http://hdr.undp.org/en/reports/global/ hdr2009/.

8. Rodrigues MN, Queiroz DM, Rodrigues RT, Rocha AM, Luz CR, Braga LL. Prevalence of Helicobacter pylori infection in Fortaleza, Northeastern Brazil. Rev Saude Publica. 2005;39(5):847-9.

9. Rollan A, Ferreccio C, Gederlini A, Serrano C, Torres |, Harris P. Non-invasive diagnosis of gastric mucosal atrophy in an asymptomatic population with high prevalence of gastric cancer. World / Gastroenterol. 2006;12(44):7172-8

10. O'Ryan ML, Rabello M, Cortés H, Lucero Y, Peña A, Torres JP. Dynamics of Helicobacter pylori detection in stools during the first 5 years of life in Chile, a rapidly developing country. Pediatr Infect Dis J. 2013;32(2):99-103.

11. Koletzko S, Jones NL, Goodman KJ, Gold B, Rowland M, Cadranel S, et al; H pylori Working Groups of ESPGHAN and NASPGHAN. Evidence-based guidelines from ESPGHAN and NASPGHAN for Helicobacter pylori infection in children. J Pediatr Gastroenterol Nutr. 2011;53(2):230-43.
12. Sachs G, Scott DR. Helicobacter pylori: eradication or preservation. F1000 Med Rep. 2012;4:7.

13. González FCG, Serrano HC, Harris PR. Diagnosis of Helicobacter pylori infection in children based on stool antigen test. Rev Med Chile. 2007;135(2):182-8.

14. Bozue JA, Johnson W. Interaction of Legionella pneumophila with Acanthamoeba castellanii: uptake by coiling phagocytosis and inhibition of phagosome-lysosome fusion. Infect Immun. 1996;64(2):668-73.

15. Michel $R$, Burghardt $H$, Bergmann $H$. Acanthamoeba, naturally intracellularly infected with Pseudomonas aeruginosa, after their isolation from a microbiologically contaminated drinking water system in a hospital. Zentralbl Hyg Umweltmed. 1995;196(6):532-44.

16. Siavoshi F, Taghikhani A, Malekzadeh R, Sarrafnejad A, Kashanian M, Jamal AS, et al. The role of mother's oral and vaginal yeasts in transmission of Helicobacter pylori to neonates. Arch Iran Med. 2013;16(5):288-94.

17. Harris $P$, Serrano C, Gonzàlez C. Utilidad del diagnóstico serológico de la infección por Helicobacter pylori en niños. Rev Chil Pediatr. 2005;76(3):24151

18. King RD, Lee $\mid C$, Morris AL. Adherence of Candida albicans and other Candida species to mucosal epithelial cells. Infect Immun. 1980;27(2):667-74.

19. García A, Barra R, Delgado C, Kawaguchi F, Trabal N, Montenegro S, et al. Genotypying of clinical isolates of Helicobacter pylori by cagA, vacA and babA2 virulence associated genes. First detection of a babA2 positive strain in Chilean patients. Rev Med Chil. 2006;134(8):981-8.

20. Ferreccio C, Rollán A, Harris PR, Serrano C, Gederlini A, Margozzini P, et al. Gastric cancer is related to early Helicobacter pylori infection in a high-prevalence country. Cancer Epidemiol Biomarkers Prev. 2007;16(4):662-7.

21. Siavoshi F, Salmanian AH, Akbari F, Malekzadeh R, Massarrat S. Detection of Helicobacter pylori-specific genes in the oral yeast. Helicobacter. 2005;10(4):318-22.

22. Torres J, Pérez-Pérez G, Goodman KJ, Atherton JC, Gold BD, Harris PR, et al. A comprehensive review of the natural history of Helicobacter pylori infection in children. Arch Med Res. 2000;31(5):431-69. 
23. Harris P, Godoy A, Guiraldes C. Dolor abdominal, dispepsia y gastritis en pediatria: rol del Helicobacter pylori. Rev Chil Pediatr. 2001;72(2):81-91.

24. Cararach M, Comino R, Davi E, Marimo E, Martínez IC, Palacios S, et al. La vulvovaginitis candidiásica recurrente. Progresos de Obstetricia y Ginecología. 2013;56(2):108-16.

25. García Heredia M, García SD, Copolillo EF, Cora Eliseth M, Barata AD, Vay CA, et al. Prevalence of vaginal candidiasis in pregnant women. Identification of yeasts and susceptibility to antifungal agents. Rev Argent Microbiol. 2006;38(1):9-12.

26. Odds FC. Candida and candidosis. 2nd ed. London: Baillie're Tindall; 1988 p.68-92.

27. Bustos R, Copaja D, Bancalari A. Candidiasis congénita en un recién nacido de muy bajo peso. Rev Chil Pediatr. 2003;74(2):193-6.

28. Bustos R, Acuña M. Infecciones por Candida en neonatología. Rev Chil Pediatr. 2006;77(3):254-8.
29. Lee A, Phillips MW, O'Rourke |L, Paster B|, Dewhirst FE, Fraser G|, et al. Helicobacter muridarum sp. nov., a microaerophilic helical bacterium with a novel ultrastructure isolated from the intestinal mucosa of rodents. Int J Syst Bacteriol. 1992;42(1):27-36.

30. Geis G, Suerbaum S, Forsthoff B, Leying H, Opferkuch W. Ultrastructure and biochemical studies of the flagellar sheath of Helicobacter pylori. J Med Microbiol. 1993;38(5):371-7.

31. Covacci A, Telford JL, Del Giudice G, Parsonnet J, Rappuoli R. Helicobacter pylori virulence and genetic geography. Science. 1999;284(5418):1328-33.

32. Faundez G, Troncoso M, Figueroa G. cagA and vacA in strains of Helicobacter pylori from ulcer and non-ulcerative dyspepsia patients. BMC Gastroenterol. 2002;2:20

33. Elitsur Y, Lawrence Z, Hill I. Stool antigen test for diagnosis of Helicobacter pylori infection in children with symptomatic disease: a prospective study. J Pediatr Gastroenterol Nutr. 2004;39(1):64-7. 